\title{
Feeding behavior and algal food of three species of abalones (Haliotis) in southern California
}

\author{
Theodore C. Tutschulte, Joseph H. Connell* \\ Department of Biological Sciences, University of California, Santa Barbara, California 93106, USA
}

\begin{abstract}
Adults of 3 species of abalones studied in southern California, USA, usually remained on their home sites, capturing either loose drift algal food or sometimes the fronds of nearby attached algae that were washed within their reach. Juveniles move and graze at night on attached microalgae. Adults prefer red to brown algae as food. Net production rate of the commonest alga, giant kelp Macrocystis, was similar to that measured at a site in central California. The amount of drift plant material was about two-thirds that found at a site in central California, and 5 times that at an offshore island. Drift Macrocystis is supplied to the study quadrats at a rate about 1.6 times the net production rate of the living plants and is distributed patchily over the sea bottom.
\end{abstract}

\section{INTRODUCTION}

The aim of this study was to describe and interpret the feeding behavior and the distribution, abundance and productivity of food of 3 coexisting California abalones: the pink, Haliotis corrugata Wood, green, H. fulgens Philippi, and white, H. sorenseni Bartsch. Adult abalones of various species are known to eat macro-algae (see, for example, Stephenson 1924, Crofts 1929, Leighton 1961, Sakai 1962, Olsen 1968, Poore 1972a, Shepherd 1973). In a laboratory study, Leighton (1966) described, for pink, green and red abalones, a food preference order for 7 species of macro-algae common in kelp beds in southern Califormia.

Sedentary marine herbivores feed in several ways; one consists of foraging from and homing to a homesite or 'scar', as has been reported for various limpets (e.g. Davis 1885, Wells 1917, Stimson 1970). A second method is to catch algae that drift within their reach. Thirdly, they may be more active, moving out over the substratum in search of food, then seeking refuge in crevices and under boulders, but not homing to any particular site. It is well known that individuals of some species of abalone that occupy scars are seldom observed in the daytime to be on a substratum other than a homesite. Many of these homesites are at some distance from stands of attached macro-algae. Moreover, the algae in the immediate vicinity of those

- Addressee for reprint requests scars that are located within the algal understory do not usually appear to be heavily grazed. Bonnot (1948) and Sinclair (1963) hypothesized that abalones occupying such sites must forage at night, grazing on attached algae at a distance from the homesite, and returning home to the scar before daylight. Alternatively, if abalones do not move away at night from the sites they are seen to occupy during the daytime, then their food must come to them. Momma \& Sato (1969) reported that although some Japanese abalones feed on drift algae, not moving at all, others move about on the substratum to feed, not returning to a homesite, while others forage for food but do return to a homesite. Poore (1972b) and Shepherd (1973) observed the first 2 types of feeding behavior in New Zealand and Australian abalones, respectively, but neither of these 2 investigators found a homing behavior in the species they were studying. Momma \& Sato (1969), then, remains the only documented report of homing behavior among abalones of which we are aware. In this paper we studied the feeding behavior of juvenile and adult abalones, the abundance and productivity of attached algae, and the kinds, amounts and spatial patterns of drift algae.

\section{STUDY AREA AND METHODS}

All studies were made in the Isthmus region of Santa Catalina Island, California, USA, within an $800 \mathrm{~m}$ radius of the coordinates $33^{\circ} 27^{\prime} \mathrm{N}, 118^{\circ} 29^{\prime} \mathrm{W}$. The 
depths and frequency of collections are described in more detail below and in Tutschulte (1976) and Tutschulte \& Connell $(1981,1988)$. This area faces northeast toward the mainland across the $32 \mathrm{~km}$ wide San Pedro channel and thus is protected from westerly and southwesterly oceanic swells and the occasional southeasterly storms that occur in this region, but is exposed to wind and waves from the northwest, north and northeast. Except during northwest storms, there is very little wave action, but the area is regularly swept by strong tidal currents that sometimes reach a speed of 3 knots. There are dense beds of giant kelp Macrocystis pyrifera (Linnaeus) C. A. Agardh along the shore and on offshore reefs. These beds extend from ca 2 to $20 \mathrm{~m}$ below MLLW. A dense understory beneath the Macrocystis canopy is comprised of a variety of red and brown algae. Deeper, between the 20 and $40 \mathrm{~m}$ depth levels, the large leaf kelps Laminaria farlowii Setchell and Agarum fimbriatum Harvey are the dominant algaI forms.

We looked for nocturnal foraging and homing behavior in adult pink and white abalones by means of time-lapse cinematography of specimens marked in situ with small luminous beacons (Tutschulte 1968). Five pinks marked by cementing tiny lights ('wheat germ' light bulbs emitting a very small amount of light) to their shells were monitored throughout the night (one frame every $10 \mathrm{~s}$ ) on 4 occasions. Kodak 4 -X reversal film type 7277 (ASA400) was used. Single whites were monitored in the same way on 2 occasions. We also made a series of day versus night diving observations of pinks and greens. We searched in the 3 to $8 \mathrm{~m}$ depth band and for each abalone found, noted its species, shell length, whether or not it occupied a scar, and whether or not it held a piece of alga underfoot. An individual was scored as feeding if it held such a piece of drift alga even though it might not have been consuming the food at the moment of observation. At one time or another, we have seen abalones actually eating all the kinds of algae that those in this sample were found to be holding. Also, we have observed repeatedly in the laboratory that abalones, once they have been fed, will not take food items offered until they are ready to feed again. This would seem to be an adaptive behavior if food is abundant because the abalone increases the risk of being dislodged from its scar by a predator each time it grasps a piece of algae and for the period it holds the food item between its foot and the substratum.

Each piece of alga held by an abalone was identified to species, except for Dictyopteris sp. and Pachydiction sp., which were grouped, Gelidium robustum, G. purpurascens, $G$. nudifrons and Pterocladia capillacea which were also grouped, and the coralline algae. We did not attempt to determine the diets of post-larvae or early juveniles, presumed to browse mainly on benthic diatoms, other single-celled algae, and corallines, as reported for several Haliotis species by various workers (Crofts 1929, Leighton 1972, Shepherd, 1973, Morse et al. 1979)

In order to learn something about the possible noctural foraging behavior of juvenile abalones, we made a series of laboratory observations of 1 - to 2-yr-old pinks. We placed such abalones, together with the rocks on which they had been found, in the centers of aquaria, $91 \times 61 \times 25 \mathrm{~cm}$ in size. These were first prepared by letting unfiltered seawater run through them for several days, causing a visible film of benthic diatoms and other small organisms to accumulate on the floor of each. Then a rock with an attached juvenile abalone still on its scar was brought in from the field, placed in the center of an aquarium and left overnight. Any noctural movements of the abalone on the floor of the aquarium left a visible track.

Table 1. Standing crop of live algae at the study site

(a) Number of fronds of Macrocystis pyrifera per $10 \mathrm{~m}^{2}$ at 3 depths, April to August 1971

\begin{tabular}{|cccc|}
\hline Depth & No. quadrats & Mean & SD \\
\hline $2.5 \mathrm{~m}$ & 15 & 77.6 & 57.8 \\
$5.5 \mathrm{~m}$ & 16 & 97.7 & 70.5 \\
$8.5 \mathrm{~m}$ & 16 & 86.9 & 54.7 \\
All depths & 47 & 87.6 & 60.7 \\
\hline
\end{tabular}

(b) Dry weight of understory algae on four $1 \mathrm{~m}^{2}$ quadrats at 5 to $6 \mathrm{~m}$ depth, November $1971\left(\mathrm{~g} \mathrm{~m}^{-2}\right)$

\begin{tabular}{|lcc|}
\hline Species & Mean & SD \\
\hline Browns & & \\
Macrocystis pyrifera & 3.73 & 5.65 \\
Sargassum palmeri & 1.0 & - \\
Dictyopteris undulata & 5.43 & 7.50 \\
Cystoseira neglecta & 37.01 & 40.88 \\
Eisenia arborea & 64.78 & 75.01 \\
Pachydictyon coriaceum & 2.23 & 3.66 \\
Reds & & \\
Plocamium cartilagineum & 55.88 & 42.32 \\
Pterociadia capillacea & 141.78 & 75.44 \\
Gelidium nudifrons & 115.58 & 78.68 \\
Carpopeltis bushiae & 14.25 & 23.49 \\
Corallina officinalis & 30.88 & 12.09 \\
Haliptylon gracile & 6.00 & 9.47 \\
Rhodymenia pacifica & 2.78 & - \\
Unidentified reds & 0.15 & - \\
Greens & & \\
Codium hubbsii & 8.75 & 6.27 \\
Urospora penicilliformis & 2.10 & - \\
All species & 451.9 & 66.5 \\
\hline
\end{tabular}


We measured the amounts of drift algae present and their rates of accumulation in 3 depth bands ( 2 to $3 \mathrm{~m}, 5$ to $6 \mathrm{~m}$, and 8 to $9 \mathrm{~m}$ ). The drift algae were collected from each of 105 quadrats $10 \mathrm{~m}^{2}$ in size $(2 \times 5 \mathrm{~m})$ censused for abalones between August 1970 and April 1972. The quadrats were located on areas of bottom containing loose rocks small enough to be turned over by divers. Within such areas, each quadrat was located haphazardly, using the criterion that it contained no more than $1 / 3$ sandy substratum. For the first 10 quadrats, only Macrocystis pyrifera, Eisenia arborea and Egregia menziesii were separately weighed; Pachydictyon coriaceum and Dictyopteris undulata were grouped, the remainder of the browns were grouped as were all the reds. Wet weights only were obtained for each species or group from these 10 quadrats. For the next 27 quadrats sampled, both wet and dry weights were obtained for each species of brown algae and for the grouped reds. Wet weights were taken after the algae had drained for an hour and been shaken in mesh bags. Dry weights were taken after the algae had been held in a drying oven overnight at $110^{\circ} \mathrm{C}$. For the remaining 68 quadrats, dry weights were obtained for each species. Dry weights of the drift algae collected from the first 10 quadrats were estimated from the ratios of dry to wet weight obtained in the second 27 quadrats (Table 7). Two methods were used to analyze patchiness of distribution of the different species among the drift algae. Constancy is the percent of quadrats containing the species; coefficient of dispersion is the ratio of the variance to the mean weight per quadrat.

We measured the accumulation rates of drift algae in the 3 depth bands in the following way. A $2 \times 5 \mathrm{~m}$ quadrat marker was first placed at each of the depths, then all drift algae in each quadrat was collected at intervals of about $3 \mathrm{~h}$. Two such series of collections were made on each of 2 quadrats at each of 3 depths in September 1971, and 3 more in April 1972, on one quadrat at each of 3 depths. We identified, dried, and weighed each species in each collection.

We estimated the standing crop of the dominant alga, Macrocystis pyrifera, by counting the fronds in 47 of the $10 \mathrm{~m}^{2}$ quadrats and multiplying by the average weight of a frond obtained from 140 fronds (stipes and attached laminae) of Macrocystis gathered from the 5 to $7 \mathrm{~m}$ depth range. To estimate the standing crop of understory species, we removed, identified and weighed all the algae (except the encrusting corallines) from four $1 \mathrm{~m}^{2}$ quadrats in the 5 to $7 \mathrm{~m}$ depth band. We obtained a conservative estimate of net primary production by removing all fronds (by cutting the stipes just above the holdfast) from 12 quadrats and counting the numbers of new plants and fronds that recolonized these quadrats over the following year. It is likely that these colonists were new recruits, since there is seldom any sprouting from holdfasts that have lost all their fronds (S. Schroeter pers. comm.).

Table 2. Population by Macrocystis of quadrats cleared in May or August 1971 and recensused in July 1972 and October 1973. (Numbers per $\mathrm{m}^{2}$ )

(a) 12 quadrats cleared and recensused once in July 1972

\begin{tabular}{|c|c|c|c|c|c|c|c|c|c|c|}
\hline \multirow{3}{*}{$\begin{array}{l}\text { Dates of } \\
\text { clearance }\end{array}$} & \multirow{3}{*}{$\begin{array}{l}\text { Depth } \\
\text { (m) }\end{array}$} & \multirow{3}{*}{$N$} & \multicolumn{4}{|c|}{ Number of plants } & \multicolumn{4}{|c|}{ Number of fronds } \\
\hline & & & \multicolumn{2}{|c|}{ Original } & \multicolumn{2}{|c|}{$\begin{array}{l}\text { Repopulation by } \\
\text { July } 1972\end{array}$} & \multicolumn{2}{|c|}{ Original } & \multicolumn{2}{|c|}{$\begin{array}{c}\text { Repopulation by } \\
\text { July } 1972\end{array}$} \\
\hline & & & Mean & $\mathrm{SD}$ & Mean & SD & Mean & $\mathrm{SD}$ & Mean & SD \\
\hline \multirow[t]{2}{*}{ May 1971} & $3-5$ & 3 & 8.3 & $(0.6)$ & 17.0 & $(3.6)$ & 150.3 & $(46.4)$ & 141.0 & $(49.4)$ \\
\hline & 9 & 1 & 5.0 & $(-)$ & 18.0 & $(-)$ & 125.0 & $(-)$ & 97.0 & $(-)$ \\
\hline \multirow[t]{3}{*}{ Aug 1971} & $5-6$ & 5 & 17.2 & $(7.8)$ & 34.2 & $(22.4)$ & 118.6 & $(69.0)$ & 139.8 & $(91.5)$ \\
\hline & 9 & 3 & 3.7 & $(2.1)$ & 29.7 & $(29.3)$ & 56.7 & $(23.0)$ & 78.7 & (52.4) \\
\hline & All depths & 12 & 10.6 & $(7.8)$ & 27.4 & $(20.0)$ & 111.6 & $(59.1)$ & 121.2 & $(69.3)$ \\
\hline
\end{tabular}

(b) 5 quadrats cleared in 2 successive years ( 4 quadrats at 5 to $6 \mathrm{~m}, 1$ at $9 \mathrm{~m}$ )

\begin{tabular}{|c|c|c|c|c|c|c|}
\hline & \multicolumn{3}{|c|}{ Number of plants } & \multicolumn{3}{|c|}{ Number of fronds } \\
\hline & $\begin{array}{c}\text { Original } \\
\text { Aug } 1971\end{array}$ & $\begin{array}{l}\text { Repop. } \\
\text { Jul } 1972\end{array}$ & $\begin{array}{l}\text { Repop. } \\
\text { Oct } 1973\end{array}$ & $\begin{array}{l}\text { Original } \\
\text { Aug } 1971\end{array}$ & $\begin{array}{l}\text { Repop. } \\
\text { Jul } 1972\end{array}$ & $\begin{array}{l}\text { Repop. } \\
\text { Oct } 1973\end{array}$ \\
\hline Mean & 13.4 & 45.0 & 28.2 & 97.8 & 165.6 & 74.2 \\
\hline (SD) & $(7.7)$ & $(19.4)$ & $(19.6)$ & $(77.3)$ & $(57.7)$ & $(48.0)$ \\
\hline Mean per yr & - & 49.1 & 22.6 & - & 180.7 & 59.4 \\
\hline
\end{tabular}


Table 3. Seasonal variation in subtidal plant drift at 3 localities in California ( $g$ wet wt $\mathrm{m}^{-2}$ )

\begin{tabular}{|c|c|c|c|c|c|c|c|c|c|c|c|c|}
\hline & $\begin{array}{c}\text { Annual } \\
\text { mean } \\
(\mathrm{SD})\end{array}$ & $\begin{array}{c}\% \\
\text { of } \\
\text { total }\end{array}$ & \multicolumn{2}{|c|}{$\begin{array}{c}\text { Winter } \\
\text { (Dec-Feb) }\end{array}$} & \multicolumn{3}{|c|}{$\begin{array}{c}\text { Spring } \\
\text { (Mar-May) }\end{array}$} & \multicolumn{2}{|c|}{$\begin{array}{l}\text { Summer } \\
\text { (Jun-Aug) }\end{array}$} & \multicolumn{3}{|c|}{$\begin{array}{c}\text { Autumn } \\
\text { (Sep-Nov) }\end{array}$} \\
\hline \multicolumn{13}{|c|}{ Catalina Island (present paper; 2 to $9 \mathrm{~m}$ depth, quadrats $10 \mathrm{~m}^{2}$ ) } \\
\hline No. quadrats: & & & & & 9 & 15 & 9 & 10 & 24 & 9 & 17 & 12 \\
\hline Year: & & & & & 1971 & 1971 & 1972 & 1970 & 1971 & 1970 & 1970 & 1971 \\
\hline Macrocystis & $\begin{array}{l}44.4 \\
(24.3)\end{array}$ & 44.1 & & & 8 & 43 & 24 & 74 & 49 & 56 & 25 & 76 \\
\hline Other browns & $\begin{array}{c}50.9 \\
(54.4)\end{array}$ & 50.5 & & & 24 & 177 & 1 & 18 & 53 & 60 & 42 & 32 \\
\hline Reds & $\begin{array}{r}5.4 \\
(41 .)\end{array}$ & 5.4 & & & 1 & 4 & 1 & 3 & 13 & 7 & 5 & 9 \\
\hline Total & $\begin{array}{l}100.6 \\
(62.3)\end{array}$ & & & & 33 & 224 & 26 & 95 & 115 & 123 & 72 & 117 \\
\hline CV: & 61.9 & & & & & & & & & & & \\
\hline \multicolumn{13}{|c|}{ Monterey Bay ( 8 to $10 \mathrm{~m}$ depth, 24 quadrats of $10 \mathrm{~m}^{2}$ at each collection; Gerard 1976 ) } \\
\hline Year: & & & 1974 & 1975 & 1974 & & 1975 & 1974 & 1975 & 1973 & 1974 & 1975 \\
\hline Macrocystis & $\begin{array}{l}102.0 \\
(76.5)\end{array}$ & 64.0 & 50 & 10 & 93 & & 25 & 235 & 75 & 85 & 195 & 150 \\
\hline Other browns & $\begin{array}{c}21.1 \\
(16.7)\end{array}$ & 13.2 & 5 & 5 & 25 & & 10 & 60 & 20 & 25 & 25 & 15 \\
\hline Reds & $\begin{array}{c}19.2 \\
(10.3)\end{array}$ & 12.0 & 10 & 5 & 15 & & 13 & 25 & 20 & 40 & 25 & 20 \\
\hline Seagrasses & $\begin{array}{c}17.1 \\
(10.6)\end{array}$ & 10.7 & 10 & 10 & 12 & & 12 & 25 & 10 & 40 & 25 & 10 \\
\hline $\begin{array}{l}\text { Total } \\
\qquad \mathrm{CV} \text { : }\end{array}$ & $\begin{array}{c}159.4 \\
(102.5) \\
64.3\end{array}$ & & 75 & 30 & 145 & & 60 & 345 & 125 & 140 & 270 & 195 \\
\hline \multicolumn{13}{|c|}{ San Nicolas Island ( $11 \mathrm{~m}$ depth, 10 quadrats of $10 \mathrm{~m}^{2}$ at each collection; Harrold \& Reed 1985) } \\
\hline Year: & & & 1981 & 1982 & 1981 & & 1982 & 1981 & 1982 & & 1982 & \\
\hline Macrocystis & $\begin{array}{c}13.9 \\
(19.1)\end{array}$ & 71.3 & 7 & 3 & 3 & & 6 & 56 & 16.5 & & 5.5 & \\
\hline Other browns & $\begin{array}{c}3.9 \\
(2.5)\end{array}$ & 20.0 & 6 & 1 & 0.5 & & 7 & 5.5 & 3.5 & & 3.5 & \\
\hline Reds & $\begin{array}{c}1.7 \\
(1.4)\end{array}$ & 8.7 & 3 & 0.5 & 0.5 & & 0.5 & 1.5 & 2 & & 4 & \\
\hline Total & $\begin{array}{c}19.5 \\
(20.2)\end{array}$ & & 16 & 4.5 & 4 & & 13.5 & 63 & 22 & & 13 & \\
\hline CV: & 104.1 & & & & & & & & & & & \\
\hline
\end{tabular}

\section{RESULTS}

\section{Live algal abundance and net production}

The average number of Macrocystis fronds counted on 47 quadrats was 87.6 per $10 \mathrm{~m}^{2}$ (Table 1a). This is equivalent to a standing crop of Macrocystis of $1.18 \mathrm{~kg}$ dry wt $\mathrm{m}^{-2}$ using the dry wt frond ${ }^{-1}(0.13 \mathrm{~kg})$ obtained as described above. The attached algal understory removed from four $1 \mathrm{~m}^{2}$ areas of rock substratum averaged $0.45 \mathrm{~kg}$ dry wt $\mathrm{m}^{2}$ (Table $1 \mathrm{~b}$ ). The ratios of wet to dry weight for all species are given in Table 7 .
The Macrocystis repopulation on 12 cleared quadrats (Table 2) shows that an average of 12.1 fronds $\mathrm{m}^{-2}$ had recolonized in about $1 \mathrm{yr}$. At an average frond wet weight of $1.11 \mathrm{~kg}$, this is equivalent to a net production of $13.4 \mathrm{~kg}$ wet wt $\mathrm{m}^{-2} \mathrm{yr}^{-1}$. Since the average life span of a frond of Macroystis pyrifera is 6 mo (North 1961), the net production estimate above should be doubled, to $26.9 \mathrm{~kg}$ wet $\mathrm{m}^{-2} \mathrm{yr}^{-1}$. The regrowth plants had fewer fronds per plant; however since there were more plants, the total population density of fronds was about the same as in the original population. This is a conservative 
Table 4. Analyses of variation in total drift algal abundance on $10 \mathrm{~m}^{2}$ quadrats. Two-way Anova with replication. Data classification by depth and by season (both fixed factors)

\begin{tabular}{|lcrrr|}
\hline $\begin{array}{l}\text { Source of } \\
\text { variation }\end{array}$ & $\begin{array}{c}\text { Degrees } \\
\text { of } \\
\text { freedom }\end{array}$ & $\begin{array}{c}\text { Mean } \\
\text { square }\end{array}$ & $F_{\mathrm{s}}$ & $p$ \\
\hline Seasons & 2 & 734.03 & 0.45 & ns \\
$\begin{array}{l}\text { Depths } \\
\text { Season } \times \text { Depths }\end{array}$ & 2 & 4070.65 & 2.49 & ns \\
(interactions) & 4 & 2210.94 & 1.35 & ns \\
Error & 63 & 1637.67 & & \\
Total & 71 & & & \\
\hline
\end{tabular}

Table 5. Variations with depth in the abundance and rates of accumulation of drift algae. The 105 quadrats ranged from 2 to $9 \mathrm{~m}$ in depth

\begin{tabular}{|c|c|c|c|c|c|}
\hline \multirow[t]{2}{*}{ Algae } & \multirow[t]{2}{*}{$\begin{array}{l}\text { Range in } \\
\text { dry weight }\end{array}$} & \multicolumn{2}{|c|}{$\begin{array}{l}\text { Regression of } \\
\text { wt vs depth }\end{array}$} & \multirow[t]{2}{*}{$r$} & \multirow[t]{2}{*}{$p$} \\
\hline & & Slope & Intercept & & \\
\hline \multicolumn{6}{|c|}{ (a) Abundance $\left(\mathrm{g} \mathrm{m}^{-2}\right)$} \\
\hline Browns & $0-260$ & -23.56 & 301.0 & -0.15 & ns \\
\hline Reds & $0-14$ & -3.46 & 33.2 & -0.30 & $\cdot$ \\
\hline \multicolumn{6}{|c|}{ (b) Rates of accumulation (g dry wt $\mathrm{m}^{-2} \mathrm{~h}^{-1}$ ) } \\
\hline Browns & $0-12.5$ & -2.44 & 27.6 & -0.24 & ns \\
\hline Reds & $0-1.9$ & -0.89 & 7.7 & -0.48 & • \\
\hline \multicolumn{6}{|c|}{$\begin{array}{l}\cdot 0.05>p>0.01 ; \text { ns: } p>0.05 \text {. Details of collections given } \\
\text { in Tutschulte }(1976)\end{array}$} \\
\hline
\end{tabular}

lower estimate of net primary production, since it neglects the amounts lost to the drift by breakage, to grazers and decomposers or as dissolved organic matter. Annual variation in net production is indicated by the quadrats that were cleared in 2 successive years (Table $2 b)$. There was a 3 -fold difference between the $2 \mathrm{yr}$ in the number of fronds repopulating the cleared quadrats.

\section{Abundance and varation of drift algae}

The quantities and seasonal variations of brown and red drift algae found on the 105 quadrats are shown in Table 3. Analysis of variance of total quantity of drift algae per quadrat classified by depth and season shows no significant differences by depth or by season (Table 4). However, separate regression analyses of brown and of red algae on depth show that, while brown drift does not vary significantly with depth, red drift diminishes significantly with increasing depth (Table 5a).

The rates of accumulation of drift are shown in Table 6. As can be seen, the standing amount of brown algal drift represents, on average over both dates, about $6.8 \mathrm{~h}$ accumulation, whereas the red algal drift represents about $4.8 \mathrm{~h}$ accumulation. The accumulation rates for brown drift do not vary with depth whereas those for red drift decline significantly with depth (Table 5b), paralleling the findings for total abundance of each type.

Among the brown algae, Egregia and Eisenia are very patchily distributed, while Macrocystis and Dictyopteris/Pachydictyon are more evenly distributed (Table 7). Macrocystis, Dictyopteris/Pachydictyon and, among the red algae, Gelidium/Pterocladia and Plocamium have a very large constancy value in the drift, when measured on the scale of $10 \mathrm{~m}^{2}$ quadrats, although the amounts present may vary over 2 orders of magnitude. The other species occur in only about half or fewer of the drift samples and where they are present the amounts may vary over 3 orders of magnitude.

\section{Feeding behavior of abalones}

The time-lapse photographic sequences made in nature showed that all of the adult pinks and whites monitored remained on their homesites throughout the night. The results of the day versus night diving observations of pinks and greens showed that about $90 \%$ of the larger individuals were on homesites during both night and day, and that about the same proportion were feeding in the daytime as at night (Table 8). All the larger individuals seen feeding were eating detached pieces of macro-algae and were on scars at the time. Most of the larger individuals were on scars whereas about half of the smaller ones were moving around. In additon, of thousands of large abalones observed during several years, many (approximately 1/3) had drift algae underfoot (T. Tutschulte unpubl.). Scores were seen capturing pieces of drift algae; virtually all of these were on homesites. Abalones have also occasionally been observed feeding on the blade of an attached Eisenia, Macrocystis, Laminaria or Agarum plant. We conclude from these observations that noctural foraging movements are not the usual method of feeding of pink, green or white abalones larger than $25 \mathrm{~mm}$ shell length and that drift macro-algae comprise the bulk of their diets.

Nocturnal movements of young (1- to 2-yr-old) pink abalones were deduced in the laboratory from tracks on aquaria floors. In each case we observed the abalone to be on a scar in the evening when the lights were turned off, and to be on the same scar at dawn the next morning, with the track of its foraging excursions clearly visible. Thus in all cases the abalone foraged during the night and homed to its scar. From these observations and the results of the field observations (Table 8 ), we conclude that 1- to 2-yr-old juvenile pink abalones forage away 
Table 6. Rates of renewal of algal drift at 3 depths. Sample sizes: 4 quadrats per depth in September 1971, 3 quadrats per depth in April 1972 (g dry wt $\mathrm{m}^{-2}$ )

\begin{tabular}{|c|c|c|c|c|c|c|c|}
\hline \multirow{2}{*}{$\begin{array}{l}\text { Depth } \\
\text { (m) }\end{array}$} & \multirow{2}{*}{$\begin{array}{l}\text { Algal } \\
\text { group }\end{array}$} & \multicolumn{3}{|c|}{ September 1971} & \multicolumn{3}{|c|}{ April 1972} \\
\hline & & $\begin{array}{c}\text { A } \\
\text { Original } \\
\text { amount } \\
\text { mean (SD) }\end{array}$ & $\begin{array}{c}\text { B } \\
\text { Accumu- } \\
\text { lation } \\
\text { rate } h^{-1}\end{array}$ & $\begin{array}{c}\text { A/B } \\
\text { Hours to re- } \\
\text { place original } \\
\text { amount }\end{array}$ & $\begin{array}{c}\text { A } \\
\text { Original } \\
\text { amount } \\
\text { mean (SD) }\end{array}$ & $\begin{array}{l}\text { B } \\
\text { Accumu- } \\
\text { lation } \\
\text { rate } h^{-1}\end{array}$ & $\begin{array}{c}\text { A/B } \\
\text { Hours to re- } \\
\text { place original } \\
\text { amount }\end{array}$ \\
\hline \multirow[t]{2}{*}{2} & Brown & $\begin{array}{c}6.00 \\
(3.20)\end{array}$ & 4.16 & 1.4 & $\begin{array}{c}2.41 \\
(0.48)\end{array}$ & 0.21 & 11.7 \\
\hline & Red & $\begin{array}{c}3.50 \\
(1.40)\end{array}$ & 0.93 & 3.7 & $\begin{array}{c}0.78 \\
(0.76)\end{array}$ & 0.09 & 8.4 \\
\hline \multirow[t]{2}{*}{5} & Brown & $\begin{array}{l}19.37 \\
(9.01)\end{array}$ & 1.62 & 11.9 & $\begin{array}{c}0.81 \\
(0.45)\end{array}$ & 0.05 & 5.5 \\
\hline & Red & $\begin{array}{c}2.29 \\
(0.25)\end{array}$ & 0.35 & 6.5 & $\begin{array}{c}0.11 \\
(0.07)\end{array}$ & 0.03 & 3.7 \\
\hline \multirow[t]{2}{*}{8} & Brown & $\begin{array}{c}18.57 \\
(20.83)\end{array}$ & 1.16 & 16.0 & $\begin{array}{c}6.17 \\
(5.58)\end{array}$ & 0.94 & 6.6 \\
\hline & Red & $\begin{array}{c}0.36 \\
(0.38)\end{array}$ & 0.10 & 3.7 & $\begin{array}{c}0.05 \\
(0.09)\end{array}$ & 0.05 & 1.0 \\
\hline \multirow[t]{3}{*}{$\begin{array}{l}\text { All } \\
\text { depths }\end{array}$} & Brown & $\begin{array}{c}14.64 \\
(13.57)\end{array}$ & 2.32 & 6.3 & $\begin{array}{c}3.13 \\
(3.68)\end{array}$ & 0.43 & 7.3 \\
\hline & Red & $\begin{array}{c}2.05 \\
(1.55)\end{array}$ & 0.46 & 4.4 & $\begin{array}{c}0.31 \\
(0.52)\end{array}$ & 0.06 & 5.3 \\
\hline & $\begin{array}{l}\text { Total } \\
\text { algae }\end{array}$ & $\begin{array}{c}16.69 \\
(13.03)\end{array}$ & 2.78 & 6.0 & $\begin{array}{c}3.44 \\
(3.62)\end{array}$ & 0.49 & 7.0 \\
\hline
\end{tabular}

Table 7. Spatial pattern of drift algae on $2410 \mathrm{~m}^{2}$ quadrat samples collected in August 1971

\begin{tabular}{|c|c|c|c|c|c|}
\hline \multirow[t]{2}{*}{ Species } & \multirow{2}{*}{$\begin{array}{l}\text { Constancy (Percent } \\
\text { quadrats on which al- } \\
\text { gal sp. found as 'drift') }\end{array}$} & \multicolumn{3}{|c|}{$\begin{array}{l}\text { Dry weight abundance } \\
\text { (g } 10 \mathrm{~m}^{-2} \text { quadrat) }\end{array}$} & \multirow{2}{*}{$\begin{array}{l}\text { Ratio } \\
\text { wet wt } \\
\text { dry wt }\end{array}$} \\
\hline & & Mean & $\mathrm{SD}$ & $\frac{\text { Variance }}{\text { Mean }}$ & \\
\hline \multicolumn{6}{|l|}{ Brown algae } \\
\hline Macrocystis pyfrifera & 100 & 59.4 & 58.5 & 57.7 & 8.19 \\
\hline Eisenia arborea & 58 & 30.8 & 129.6 & 545.7 & 5.97 \\
\hline Egregia menziesii & 33 & 55.7 & 225.5 & 912.4 & 4.14 \\
\hline $\begin{array}{l}\text { Dictopteris undulatal } \\
\text { Pachydictyon coriaceum }\end{array}$ & 100 & 17.9 & 24.9 & 34.7 & 6.28 \\
\hline Other brown algae & 63 & 1.9 & 2.6 & 3.4 & - \\
\hline Halidrys sp. & - & - & - & - & 5.74 \\
\hline Cystoseira neglecta & - & - & - & - & 5.27 \\
\hline \multicolumn{6}{|l|}{ Red algae } \\
\hline $\begin{array}{l}\text { Gelidium spp./ } \\
\text { Pterocladia capillacea }\end{array}$ & 96 & 13.4 & 21.7 & 35.3 & - \\
\hline Plocamium cartilagineum & 96 & 8.2 & 9.9 & 12.0 & - \\
\hline Gigartina spinosa & 29 & 1.4 & 3.9 & 10.5 & - \\
\hline Corallines & 46 & 5.2 & 13.8 & 36.6 & - \\
\hline Other red algae & 54 & 0.9 & 1.6 & 3.1 & 4.37 \\
\hline Total & & 194.8 & & & 6.03 \\
\hline
\end{tabular}

from a homesite and are more active at night than during the daytime. Few pinks or greens, if any, establish themselves on a scar in the first year of life and some may not do so until the third year, judging age from growth rates (Tutschulte \& Connell 1988).

\section{Diet and food preferences of abalones}

The proportion of a food item in the diet as compared to its availability in the environment may be used as a measure of food preference. The data summarized in 
Table 8. Haliotis corrugata and $H$. fulgens. Field observations of feeding and movements of pink and green abalone

\begin{tabular}{|cccccc|}
\hline Species & $\begin{array}{c}\text { Time } \\
\text { of } \\
\text { day }\end{array}$ & $\begin{array}{c}\text { Shell } \\
\text { length } \\
\text { (mm) }\end{array}$ & $\begin{array}{c}N \\
\text { Percent } \\
\text { on } \\
\text { scar }\end{array}$ & $\begin{array}{c}\text { Percent feed- } \\
\text { ing on drift } \\
\text { macro-Algae }\end{array}$ \\
\hline $\begin{array}{c}\text { H. corrugata } \\
\text { (Pink) }\end{array}$ & & & & & \\
& Day & $>25$ & 138 & 95.7 & 18.9 \\
& Day & $\leq 25$ & 28 & 42.9 & 0 \\
& Night & $>25$ & 28 & 89.3 & 14.3 \\
& Night & $\leq 25$ & 2 & 50.0 & 0 \\
H.fulgens & & & & & \\
(green) & Day & $>25$ & 51 & 84.4 & 19.6 \\
& Day & $\leq 25$ & 2 & 50.0 & 0 \\
& Night & $>25$ & 16 & 87.5 & 25.0 \\
& Night & $\leq 25$ & 0 & - & - \\
\hline
\end{tabular}

Table 9 suggest that Haliota corrugata (pinks) eat the brown algae Macrocystis and Dictyopteris/Pachydictyon in the proportions in which these algae occur in the drift, while selecting Eisenia, Plocamium and probably corallines, and avoiding Egregia. H. fulgens (greens) eat Macrocystis, Eisenia and corallines in the proportions in which they occur, avoid Egregia, and select the red algae Gelidium/Pterocladia, Plocamium and Gigartina.

\section{DISCUSSION}

Our results indicate that young juvenile Haliotis corrugata (pink) and $H$. fulgens (green) abalones occupy crevices of other cryptic sites in the daytime, moving out to forage at night and returning to their homesites before dawn. We did not study the possible nocturnal foraging and homing behavior of juvenile
H. sorenseni (whites), but since we found so few of them in our searches in areas of great density of older members of this population, and have no evidence for immigration of juveniles of this species from some nursery area elsewhere, we believe that juvenile whites also hide in the daytime and forage in the open at night.

Older juveniles and aduits of all 3 species remain on homesites, not moving off at night to forage. Rather, they capture drifting pieces of macro-algae that pass near their scars. Older whites and pinks, and perhaps greens as well, also graze occasionally on attached algae when currents move the fronds close enough to be caught.

On average, brown algae were about 18 times as common in the samples of drift as were red algae (Table 3), yet the average rate of accumulation of browns is only about 6 times that of reds over the same depth range (Table 6). This suggests that red drift algae may be consumed at a faster rate relative to their rate of production than are brown drift algae, i. e. perhaps the red component is being selectively removed from the mixture of drift plants. Both species of abalone seem to prefer red algae to brown. The same preference was found for 2 species of abalone in New Zealand (Poore 1972a) and for 5 species of abalone in South Australia (Shepherd 1973).

The disparity between the results shown here for Egregia (low apparent preference level) and Leighton's (1966) report that both pinks and green show a preference for Egregia in the laboratory may be due to our small numbers of feeding observations and the patchy distribution of this alga in the area that we sampled. However it may also reflect the more natural behavior of abalones feeding under field conditions.

Table 9. Observations of algae being eaten by abalones as compared to drift algae present over the same depth range, August and September 1971. Probable preferences shown as: prefer: +; avoid: -; no preference: 0

\begin{tabular}{|c|c|c|c|c|c|c|c|}
\hline \multirow[t]{3}{*}{ Alga species } & \multicolumn{6}{|c|}{ Drift algae being eaten by abalones in September 1971} & \multirow{3}{*}{$\begin{array}{c}\text { Drift algae on } \\
\text { substratum } \\
\text { (from Table } 7 \text { ) } \\
\% \text { total }\end{array}$} \\
\hline & \multicolumn{3}{|c|}{ H. corrugata (pinks) } & \multicolumn{3}{|c|}{ H. fulgens (greens) } & \\
\hline & No. obs. & $\%$ total & Preference & No. obs. & $\%$ total & Preference & \\
\hline Macrocystis pyrifera & 9 & 29 & 0 & 5 & 28 & 0 & 30.5 \\
\hline Egregia menziesii & 3 & 10 & - & 1 & 6 & - & 28.6 \\
\hline Eisenia arborea & 9 & 29 & + & 3 & 17 & 0 & 15.8 \\
\hline Dictyopteris/Pachydictyon & 3 & 10 & 0 & 1 & 6 & 0 & 9.2 \\
\hline Gelidium/Pterocladia & 1 & 3 & 0 & 5 & 28 & + & 6.9 \\
\hline Plocamium cartilagnineum & 4 & 13 & + & 2 & 11 & + & 4.2 \\
\hline Corallines & 2 & 6 & + & 0 & 0 & 0 & 2.7 \\
\hline Other brown algae & 0 & 0 & 0 & 0 & 0 & 0 & 1.0 \\
\hline Gigartina spp. & 0 & 0 & 0 & 1 & 6 & + & 0.7 \\
\hline Other red algae & 0 & 0 & 0 & 0 & 0 & 0 & 0.5 \\
\hline Totals & 31 & & & 18 & & & 100.0 \\
\hline Percent of all brown algae & & 77 & 0 & & 56 & - & 85.1 \\
\hline Percent of all red algae & & 23 & + & & 44 & + & 14.9 \\
\hline
\end{tabular}


The mean annual amount of drift algae of all types on our site was about two-thirds that reported by Gerard (1976) from a kelp forest in Monterey Bay, California, (Table 3), and several times that found at San Nicolas Island (Harrold \& Reed 1985). In all 3 studies there were some seasonal variations in the amount of drift, with most occurring in the warmer water seasons. San Nicolas Island showed a somewhat greater seasonal variation than the other 2 sites, judging by its greater coefficient of variation (Table 3). Macrocystis dominated the drift at the Monterey Bay and San Nicolas Is. sites, but not at our Catalina site, where other species of brown algae were more abundant. This contrast probably reflects a difference among these sites in the species composition of the larger algae.

Our estimates of net production of Macrocystis, $26.9 \mathrm{~kg}$ wet wt $\mathrm{m}^{-2} \mathrm{yr}^{-1}$, compares well with that of Gerard (1976), $23 \mathrm{~kg}$ wt m $\mathrm{m}^{-2} \mathrm{yr}^{-1}$. The accumulation rates of drift Macrocystis on the cleared quadrats was $43.9 \mathrm{~kg}$ wet wt $\mathrm{m}^{-2} \mathrm{yr}^{-1}$, about 1.6 times the rate of net production. The reason why the rate of accumulation of Macrocystis drift exceeds its net production is probably because, as pieces are broken from attached kelp, they do not accumulate evenly on the sea bottom. Instead, they may be washed about until they are trapped in crevices and hollows. Our quadrats were all located in areas with loose rocks and boulders, which would tend to trap the drift algae. Some of the substratum in this kelp bed consists of patches of sand which do not trap drift plants. Thus the drift appearing in our quadrats was probably concentrated from a larger area of production in the kelp bed as a whole.

Acknowledgements. We thank S. Schroeter for assistance in statistical analysis, him and A. J. Underwood for comments on the manuscript, and R. Given for the photographs in the laboratory; a host of fellow graduate students helped in diving and collecting. We also thank the staff of the University of Southern California, Santa Catalina Marine Biology Laboratory, for their hospitality in providing laboratory space and equipment.

\section{LITERATURE CITED}

Bonnot, P. (1948). The abalones of California. Calif. Fish Game 34: $141-169$

Crofts, D. R. (1929). Haliotis. Liverpool Mar. Biol. Comm. Mem. No. 29, p. 1-174

Davis, J. R. (1885). The habits of the Limpet. Nature, Lond. 31: 200-201

Gerard, V A. (1976). Some aspects of material dynamics and energy flow in a kelp forest in Monterey Bay. California. Ph. D. dissertation, University of Califomia, Santa Cruz
Harrold, C., Reed, D. C. (1985). Food availability, sea urchin grazing, and kelp forest community structure. Ecology 66: $1160-1169$

Leighton, D. L. (1961). Observations of the effect of diet on shell coloration in the red abalone Haliotis rufescens. Veliger 4: 29-32.

Leighton, D. L. (1966). Studies of food preference in algiverous invertebrates of southern California kelp beds. Pacif. Sci. 20: $104-113$

Leighton, D. L. (1972). Laboratory observations on the early growth of the abalone, Haliotis sorenseni, and the effect of temperature on larval development and settling success. Fish. Bull. U. S. 70: 373-381.

Momma, H. Sato, R. (1969). The locomotion behavior of the disc abalone, Haliotis discus hannai Ino, and the Siebold's abalone, Haliotis sieboldi Reeve, in the fishing grounds. Tohoku J. Agric. Res. 20: 150-157.

Morse, D. E., Hooker, N., Jensen, R., H. Duncan (1979). Induction of larval abalone settling and metamorphosis by $y$-aminobutyric acid and its congeners from crustose red algae: II: applications to cultivation, seed-production and bioassays; principal causes of mortality and interference. Proc. World. Maricult. Soc. 10: 81-91

North, W. J. (1961). Life span of the fronds of the giant kelp, Macrocystis pyrifera. Nature, Lond. 190: 1214-1215

Olsen, D. A. (1968). Banding patterns in Haliotis - II. Some behavioral considerations and the effect of diet on shell coloration for Haliotis rufescens, Haliotis corrugata, Haliotis sorenseni, and Haliotis assimilis. Veliger 11: 135-139

Poore, G. C. B. (1972a). Ecology of New Zealand abalones, Haliotis species (Mollusca: Gastropoda) 1. Feeding. N. Z. Jl mar. Freshwat. Res. 6: 11-22

Poore, G. C. B. (1972b). Ecology of New Zealand abalones, Haliotis species (Mollusca: Gastropoda) 2. Seasonal and diurnal movement, N. Z. Jl mar. Freshwat. Res. 6: 246-258

Sakai, S. (1962). Ecological studies on the abalone, Haliotis discus hannai Ino IV. Studies on the growth. Bull. Jap. Soc. scient. Fish. 28: 899-904

Shepherd, S. A. (1973). Studies on southern Astralian abalone (genus Haliotis) 1. Ecology of five sympatric species. Aust. J. mar. Freshwat. Res. 24: 217-257

Sinclair, M. (1963). Studies on the Paua, Haliotis iris Martyn in the Wellingston district, 1945-46. Zool. Publ. Victoria Univ., Wellington, No. 35, p. 1-16

Stimson, J. (1970). Territorial behavior of the owl limpet, Lottia gigantea. Ecology 51: 113-118

Stephenson, T. A. (1924). Notes on Haliotis tuberculata. I. J. mar. biol. Ass. U. K. 13: $480-495$

Tutschulte, T. C. (1968). Monitoring the nocturnal movements of abalones. Underwat. Natur. 5: 12-15

Tutschulte, T. C. (1976). The comparative ecology of three sympatric abalones. Ph. D. dissertation, University of California, San Diego

Tutschulte, T C., Connell, J. H. (1981). Reproductive biology of three species of abalone (Haliotis) in southern California. Veliger 23: 195-206

Tutschulte, T. C., Connell, J. H. (1988). Growth of three species of abalone (Haliotis) in southern California. Veliger (in press)

Wells, M. M. (1917). The behavior of limpets with particular reference to the homing instinct. J. Anim. Behav. 7: 387-395 